\title{
Global and Local: Rethinking citizenship in art and visual culture education
}

\author{
La globalización y el Pueblo: Una \\ reconsideración de la ciudadanía en la \\ educación del arte y la cultura visual
}

\section{La globalization et le village: un reéxamen de la citoyenneté dans la education de l'art et la culture visuelle}

\author{
Elizabeth Garber \\ University of Arizona, United States
}

\section{ABSTRACT}

Global colonization by the world's dominant cultures is a recurring theme in academic discourses. Participatory democracy (as differentiated from other concepts of democracy) is threatened by globalization because international corporations are beyond the control of nation-states. Yet thinking of globalization as bad or the local as remedy is overly reductive. In education, it is up to teachers and theoreticians to develop means to guide students to understand, explore, and live in the globalized world. Based on these theoretical premises, five principles are developed that provide a basis for art and visual culture teaching practice: identity, understanding beyond oneself, race/class/gender awareness, becoming political subjects, and transgression and play.

Key words: globalization; democracy; citizenship; art and visual culture education; cultural and social diversity; social justice.

\section{RESUMEN}

La colonización contemporánea del mundo por las culturas dominantes es tema recurrente en los discursos académicos. La democracia participatoria (que es diferente de otras concepciones de la democracia) está amenazada con la globalización porque las corporaciones internacionales están afuera del control de los países. No obstante, pensar en la globalización en términos absolutos como "mala" o en el "pueblo" como una solución es simplificada excesivamente. Los maestro/as y erudito/as deben desarrollar métodos para guiar a los estudiantes para que 
entiendan, exploren, y vivan como ciudadanos mundializados. Con estas premisas, se propone la autora cinco principios para construir una fundamento para enseñar la arte y la cultura visual. Estos principios son desarrollados: la identidad del individuo; el comprensivo más grande que el individuo; la conciencia de diferencias entre los raíces, las clases sociales, y el género; la conciencia de la natura política de la educación; y las dimensiones transgresivas de la educación.

Descriptores: globalización; democracia; ciudadanía; el arte y la cultura visual; la diversidad cultural y social; la justicia social.

\section{RÉSUMÉ}

La colonisation du monde pour les cultures dominantes est un thème récurrent dans les discussions académiques. La démocratie participative (ça qu’est différente que les autres genres de la démocratie) est menacé avec la mondialisation par ce que les corporations internationaux ne sont pas gouvernées pour les pays. Quand même, on ne doive pas penser en la mondialisation comme quelque chose complètement mauvais, ou le village comme un remède élémentaire. Il faut que les enseignants et les érudits élaborer les méthodes pour guider les étudiantes vers être citoyennes mondiales. L'auteur propose cinq principes pour construire la fondation de l'enseignement de l'art y la culture visuelle. Ils sont élaborés : l'identité de l'individu; la compréhension plus grande que l'individu; la conscience entre les races, les clases sociales, y les sexes; la conscience de la nature politique de l'éducation; y les dimensions transgressives de l'éducation.

Mots clés : mondialisation ; démocratie ; citoyenneté ; I'art et la culture visuelle ; la diversité culturale et sociale ; la justice sociale

\section{Globalization}

Rurger king restaurants from Helsinki to Seoul to Mexico City, US sit-coms 3 and blockbuster films dubbed in Chinese, Estonian, and Hindi; Microsoft as the prevailing software in Ankara, Makarora, Nuuk, and Tierra del Fuego: these are signs of global colonization by the world's dominant cultures, especially that of North America. Globalization is a recurring theme in academic discourses.

In Europe, Asia, and the Americas . . . [economic and commercial] markets have already eroded national sovereignty and given birth to a new class of institutions - international banks, trade associations, transnational lobbies like OPEC, world news services like CNN and the BBC, and multinational corporations - institutions that lack distinctive national identities and neither reflect nor respect nationhood as an organizing or a regulative principle. While mills and factories sit somewhere on sovereign territory under the eye and potential regulation of nation-states, currency markets and the Internet exist everywhere, but nowhere in particular. (Barber, 1995, p. 14)

What is alarming about Barber's thesis is his argument that global capitalization is beyond the control of nation states. It puts corporations outside any form of regulation and poses problems for democracy and citizenship. ${ }^{1}$

The origins of current globalization are variously traced to the merging of small businesses under larger ones (Bagdikian, 2000), to communication technologies, and 
to migration patterns. Nation-states retain vitality but cannot control their borders because they are subject to significant internal and external pressures from capitalism (Held, 1995). Global capitalism, or “designer capitalism” as jagodzinski (2008) refers to it, is often thought of as the new kind of colonialism, invading cultures and societies worldwide with values and life styles that promote a westernized (arguably North American) way of life that is pictured in movies, on television, and in magazines. Reasons why this is a negative phenomenon are largely based on "cultural emasculation" (Morley \& Robins, 1995, p. 53), meaning that global culture replaces regional culture, values, and customs. Other reasons have to do with loss of identity and agency (Baudrillard, 2002).

Many histories (fictive or so-called "factual") are written of the non-Western world from a Western view and are "so ingrained as to blind [the writer] to other histories, other cultures, other aspirations" (Said, 1993, p. xviii) — which is a type of colonization. Using Joseph Conrad's novel Nostromo: A Tale of the Seaboard (1904), Said argues that Conrad sees India, Africa, and South America only from the eyes of the West and that he misses the fact that the people in these countries "had lives and cultures with integrities not totally controlled by the gringo imperialists" (p. xviii). In other words, Conrad, in writing an anti-imperialist novel, makes the mistake of seeing the colonized (people and culture) only as colonized and not in any way as independent from the colonizers. Said's more contemporary examples of this phenomenon are films such as Costa-Gavras' Missing, Stone's Salvador, and Coppola's Apocalypse Now. In art, early modernists looked at African and Japanese art as form, but neither investigated the meanings of the art within the originary cultures nor did they look at the art beyond form. Said points out that such limitations conceptualize that,

the source of the world's significant action and life is in the West, whose representatives seem at liberty to visit their fantasies and philanthropies upon a mind-deadened Third World. In this view, the outlying regions of the world have no life, history, or culture to speak of, no independence or integrity worth representing without the West. (p. xix)

In this paper, I will first lay out ideas about democracy and globalization. Then I will discuss from the standpoint of postcolonial theory some limitations to the global vs. local debate and suggest that understanding must extend more deeply. From here, I will describe how this theory takes shape in my own teaching and offer four goals I work with in preparing future art and visual culture educators. I will conclude with some thoughts on the meaning of multicultural citizenship in the teaching of art.

\section{Globalization and Democracy}

Barber's (1995) goal that nations be governed democratically is one that underlies education in free world ideologies. But what does this grand word "democracy" operationally mean? Torres (1998) distinguishes between formal and substantive 
democracy. Formal democracy is democracy that excludes: largely advanced by white heterosexual males in positions of power, it puts forth a model of democracy that benefits certain people but not others. Capitalist societies, with competing interests between workers, managers, and owners, depend on differential power structures: on hierarchies in both the workplace and in political structures that are needed to maintain these differentiations. Distinct from formal democracy is substantive democracy, based on equal representation, equity, and equality among all people. Torres puts forth four models of democracy based on the work of C.B. Macpherson (1962; 1973). These are:

"protective democracy," which is based on the hegemony of a market economy "to advance market interests and to protect against the tyranny of the state";

"developmental democracy, based on elevating working-class people into rational beings who are 'self-interested consumers and appropriators' and democratic participators";

"equilibrium democracy" (or "pluralist democracy"), where apathy among the majority of citizens is crucial to a functioning democracy because participation "'overloads the system with demands which it cannot meet"; and

"participatory democracy," in which socially equal and conscious individuals contribute to building "a sense of community, of association, of neighboring and joining.” (pp. 146-147)

Protective, developmental, and equilibrium models of democracy are all forms of formal democracy. They support the differentiations between worker and management/ owner, the role of workers as "consumers" rather than "citizens" who are in knowledgeable governance, and apathy (often through consumption and meeting desires created by advertising) towards governance. Participatory democracy is the only type of substantive democracy in Macpherson's outline, and the goal of the art and visual culture education described in this paper because education towards social justice requires reflective, informed citizens willing to work towards equality and respect for all individuals and groups.

\section{Postcoloniality ${ }^{2}$}

"Does [globalization] promote cultural sharing, tolerance, and a cosmopolitan spirit, or does it yield only the illusion of such understanding, a bland, consumerist appreciation, as in a Disney theme park, which elides issues of conflict, difference, and asymmetries of power?" ask Burbules \& Torres (2000, p. 14). "Evils" of globalization include labor issues — including poor working conditions and salaries on which workers cannot live, an increased gap between rich and poor, an increase in urban violence, and a threat to cultural identity and ideals of participatory democracy. In education, schooling as business, reflected in the rise of for-profit educational 
institutions at both the $\mathrm{K}-12$ and university levels, can be thought of as "negative."

With the rise of capitalism and international corporations, the nation-state is more complex, less substantively democratic and more hierarchical (ergo less participatory). Problems of complex capitalist states require technical expertise. "The protagonist of industrial society is the scientist, the specialist, the expert; the protagonist of the democratic society is the common citizen, the man in the street, the quisque e populo'" (Torres, 1998, p. 159, citing Italian political scientist Roberto Bobbio). Education gets caught in the confusion between the education of specialists and the development of critical, reflective, and participatory citizens.

Globalization, of course, is not always thought of negatively. For citizens of wealthier nations, it means greater access to travel, goods, information, and technologies. From the perspective of Western values, some features of globalization can be thought of as "positive." Chakrabarty (2000), for example, refers to modern Europe not as a place but as "habits of thought." Among European thought habits are citizenship, human rights, individuality, and social justice. These "habits" are usually assumed as universal values and concepts, and many social critiques, he argues, are based in them. The ideas of democracy and the perceptions of globalization that I present in this paper are based in these habits, which can be traced to the Enlightenment (Torres, 1998). In education, these values include universal access to literacy and other forms of education regardless of economic status, gender, race, or other identify factors; education for peace, tolerance, and democracy; and eco-pedagogy. Some of these values are historically traced to non-Western cultures, but currently it is the globalization of Western ideas and values through which they often take root. Thus simple dualities between democracy and globalization; specialist and citizen; global and local, regional, or nation; or colonizer and colonized need to be dispelled. The reality is more complex.

Duncum (2001) and Bae (2009) argue that there are many other exporters of culture besides North America, especially noting Japan, China, and India. Bae notes the phenomenon of hanryu, or the Korean Wave, that has swept East and South Asia over the past decade and involves TV dramas, popular music, movies, music videos, fashion, food, accessories, and mobile phones. "Such an alternative discourse defies the idea of the US as the center of cultural power and its influence on the rest of the world...there are many emerging centers of cultural power in other parts of the world" (p. 180). Duncum also notes that widespread access to technology enables local productions and their virtually free export.

The transmission of culture from one country to another and cultural translation are not the same thing. Transmission is what happens at a purely technological level whereas the translation of cultural goods involves human agency; translation is a rich, generative process involving the production of a text that may be more or less than, but is always different from, the original. (n.p.)

While it is historically factual that many nations have been colonized or have colonized others, this binarism continues an "us" and "they" (Said,1993). To extend 
beyond binary thinking is one of the premises of postcolonial theory. Understanding of cultures other than one's own must extend beyond the boundaries of an individual's or a group's cultural perceptions of that group because societies and cultures are varied and complex.

Furthermore, experiences of colonized and colonizer overlap and are interdependent: an imperialist culture is not distinct, separate, or monolithic, just as a colonized nation is not. "Partly because of empire, all cultures are involved in one another; none is single and pure, all are hybrid, heterogeneous, extraordinarily differentiated, and unmonolithic" (Said, 1993, p. xxv). Cultures can be diverse yet whole, with a single culture being in itself an "ethnographic collection" (Clifford, 1988, p. 230). "Globalization is not a monolithic and static process but a dynamic one" (Kim, 2009, p. 25). The example of Coca-Cola is apt, for it has long been associated with United States cultural imperialism in showing up in the most remote places and displacing local drinks. Within some of these cultures, however, it is attributed local meanings:

In Russia it is thought to smooth wrinkles; in Barbados, to turn copper into silver; and in Haiti, even to revive the dead. It is often mixed with local drinks to produce new brews, and in many different places people appear to believe that it originates in their own country. . .where a culture is influenced by another what occurs is not a take over but a translation. (Duncum, 2001, n.p., drawing on the work of Howe, 1996)

Educators, then, must be careful in representing culture - especially those of which they are not a part - for this representation influences how cultures are thought about. Educators, as guides, can contribute to students' sensitivity to diverse life styles, values, and beliefs and to their understanding of the complexities of global colonization and national, local, and individual identities. Educators have a chance to contribute to the development of students as participatory, global and local citizens.

\section{Education}

The effects of globalization and strategies for developing the local, for appreciating cultural diversity, and creating social justice through the arts are recurring themes in education. They threaded through the UNESCO $2^{\text {nd }}$ World Conference on Arts Education held in Seoul in May, 2010 (e.g., Aoun, 2010; jagodzinski, 2010; Lyndersay, 2010; Pillai, 2010; Ward, 2010). Several authors writing about art education have addressed them. Duncum (2001), for example, has suggested students investigate their own local heritage through tourist artifacts. Tavin and Hausman (2004) document a class they taught for pre-service art teachers where they focused on investigating global corporations that purvey Western values, such as Hard Rock Café. Grauer (2002) worked with teens to examine their bedroom decorations in terms of a Coke-sponsored marketing strategy, "the global teenager." Stanley (2005) had high school students compare Disney's promotional material with their own experiences of the Sleeping Beauty Castle and with the original story to see how it 
changes in each context and to consider why. Toku (2001) considered the globalization of imagery from Japanese comic books.

In my own teaching, I have been working with students to find ways

- to understand how culture influences an individual's values, experiences, and understandings of the world and to help students understand how their identities get caught up in consumer ideals;

- to know, understand, and value cultures beyond the dominant ones and to look at a broad range of art making, especially local and regional art and collaboratively produced and socially oriented art;

- to begin the painful process of looking into how racism is embedded in United States culture and implicates everyone; and

- to inspire them to find ways to take action against corporate forms of culture that perpetuate bias and colonialistic attitudes, and to work for change through art that will support social justice within the communities or schools where they will live and work.

My goals are consistent with "reconstructionist" multicultural education, ${ }^{3}$ and also with feminist, postmodernist, and postcolonial ideals, along with principles of sustainability. They take shape as a set of five principles for teaching: identity, understanding beyond oneself, race/class/gender awareness, becoming political subjects, and transgression and play. These principles developed over a period of several years while working with students, and are elaborated below.

Identity is a theme in multicultural writing and education, as well as in some contemporary art and art discourse. Strong identities are a prerequisite to respecting individuals and cultures outside of oneself, and to developing a sense of agency. Bourdieu (1984) urges individuals consider their own positions, asking in what field of power and from what position in that field one writes, speaks, or understands. Students and their development as individuals are one of the centres of the process of art and visual culture education (Wasson, Stuhr, \& Petrovich-Mwaniki,1990).

Yet identity can be misunderstood as making monograms or collages of self-identification that touch only on superficial levels of understanding identity. Identity study should not "reduce knowledge to social position or interest per se but, rather, to place all of these variables within the complex constraints - Bourdieu's habitus within which they are produced and received" (Rabinow, 1986, p. 252). Exploration of one's self needs to develop in a larger framework of consumer culture and cultural, class, ethnic, racial, and national studies. It must be pursued in the context of critical and reflective questioning and thinking.

Further, identity must be understood as shifting and ever changing in two ways. First, identity changes over the course of a lifetime; it is not fixed. In any one moment, an individual has multiple and sometimes conflicting identities: I, for example, variously occupy positions of researcher and scholar, teacher, activist, mother, wife, gardener, rower, cyclist, artist, friend, etc. Second, identity is how others perceive an individual or group. Resemblance is relative to the culture and the purpose of classification. In The Twilight of Common Dreams, Todd Gitlin eloquently notes, 
To a passerby or a census-taker, I am white. To an anti-Semite, I am simply a Jew. To a German Jew, I may be one of the Ostjuden; to Sephardiim, an Ashkenazi Jew; to an Israeli Jew, American; to a religious Jew, secular; to a right wing Zionist, an apostate, or no Jew at all. (cited in Torres, p. 178) ${ }^{4}$

Identity is how individuals and groups understand themselves in relation to others. It is an ongoing reflective and developmental process. In art, it must involve exploration of what is not obvious to students about themselves, as well play. Play includes trying on different identities using different artistic styles or conveying different messages, which allows the maker to put him or herself in a different role than they usually see themselves. It can mean indulging in various forms of fan art (writing additional episodes for The X-Files in which the person inserts him or herself, for example) or playing with a medium in a new way so to experiment with and express a new meaning, Indeed, art class is a key arena for such growth and exploration.

Understanding beyond oneself. A lot of art instruction takes place in relationship to self-expression. Knowledge about art and the world beyond oneself, however, remains critical to being educated in art as well as in any other subject. In my classes, we look at what understanding we can develop from art and artifacts. We look at artworks in relation to an artist's/maker's culture. We also begin to consider students' own cultural norms and the ideas they hold about the cultures they are studying so that we talk about art in different ways. We begin the processes of taking care not to simplify an artwork in relation to the artist's culture or to simplify a culture (as I have written elsewhere, mariachi music and milagros should not represent the whole of Mexican art [1995]). In interviews with artists who are different racially, ethnically, or sexually from themselves, the real focus of students' investigations is not on the facts they learn from the artist, but their own internalization and reflections on their meeting. Their interviews with artists and research into the artists' cultures result in a mediation on and inquiry into cultural diversity and representation.

In teaching for a participatory democracy, investigating the indigenous, the local, and the regional make a ready link to students' lives. The local can help build stronger communities, engender a sense of involvement and possibility for change, and help us communicate with a variety of people. Although students are often ready to celebrate local and untrained ("folk") art and artists, I try to instill in them a willingness to look at the complexity of influences on any artist and the web of their own values and beliefs. I want them to understand that the substitution of "local" for "global" or "capitalist" is not a simple remedy, that the local can insulate us from understanding the variety and complexity of people and their ways, especially in communities that are homogeneous.

The position I navigate students towards is that of "border" crossers. Literary scholar Tomás Ybarra-Fausto (1986) and artist Guillermo Gomez-Peña (1986) have advanced the notion of "border" as a metaphor for positive change resulting in hybrid cultures and hybrid thinkers. Ybarra-Fausto notes that the culture of Mexican-Americans draws on two sets of reference codes - Mexico and the United States - that operate simultaneously, creating a cultural montage and a borderland 
that is both and then some. Gomez-Peña (1986) argues that "'we must learn each other's language, history, art, literature, and political ideas.' We must travel south and east, with frequency and humility, not as cultural tourists" (p. 97). We must study individually to understand the varieties and subtleties of the culture we teach or write about and with a thoroughness that exceeds most current calls to "multiculturalism." The term has made its way into education through the writings of Paolo Freire and Henry Giroux. In Giroux's Border Crossings (1992), he used the concept as a way to formulate the role cultural workers (teachers, postmodern theorists, feminists, and others) might play in the development of a critical pedagogical practice that works across these disciplines. In a 1995 article that drew on Gomez-Peña's (1986) call to become a border crosser, I argued that the study of cultures other than one's own be approached for the formation of a "border consciousness" and that this should be a basic component of education. The point is that education be a path to opening students and teachers to learning about and with others, and developing a world where each person crosses borders to work and live respectfully with others (Garber, 1995).

Class, race, and gender. Racism and class and gender bias are deeply embedded in many cultures although proscribed by laws and countered by educational principles. With my students, we learn about race and ethnicity theoretically. We learn that there are three types of racism: individual, institutional, and cultural, and different models of racial identity (Helms, 1990, 1994, 1995)..$^{5}$ We study theories of ethnicity. We consider how being white accrues both human rights that are at times denied other people and how it also offers unearned privileges (McIntosh, 1988/1989). We look at our own positions in society, asking what field of power and from what position we act and understand. I ask students to confront "white" as a cultural space that has personal psychological significance but is not the invisible of so-called "mainstream" culture (Roman, 1993; McLaren, 1997). We read an account by Cornell West (1994), as a well dressed black man and a leading intellectual in the United States, of taxicab drivers refusing to pick him up. We look at disparity between schools in inner cities (with primarily black, Latina/o, or other non-white students) and in United States suburbs - despite federal spending that is meant to offer the same education to all children (Kozol, 1991). We explore the pervasiveness of gender as an influence in our lives as well as its significance to the art classroom (Sadker \& Sadker, 1995; Garber, Sandell, Stankiewicz, \& Risner, 2007). We look at our own positions in society, asking what field of power and from what position we act and understand. We consider these factors in relationship to the ideal of a participatory democracy that is a foundation of social justice. These are not easy conversations.

Students engage in a variety of projects, beginning with letters to themselves (Lippard, 1990) and classmate interviews that include gender, class, cultural, and racial identities. They create images of themselves as they view themselves and from the imagined perspectives of how the opposite sex views them and the same sex views them. They comb the Internet for visual culture tidbits to share and discuss in class. They listen to artists from various backgrounds talk about their work. They research a culture that is not their own and interview an artist or art teacher from that culture. 
They look at how art teachers present identity issues in their classrooms or observe teaching in diverse classrooms. Some take issues to the community in various forms of activism involving art (e.g., performances or interactive artwork). Others, who are already teachers, develop lessons or curriculum to rethink their teaching of diversity. These projects are based on the sequence of learning that occurs in the class.

Whereas students readily learn the cultural narratives of "others," if they do not learn about themselves, those about whom they learn about remain "other." They often find this confrontation with themselves an extremely emotional process. Torres (1998) writes that "an antiracist pedagogy that takes seriously the nuances of the white experience should enable white students to move beyond positions of guilt and resentment" (p. 177). An understanding of whiteness should help students grow into anti-racists who willingly take on an active role in insuring democracy (a radical form of democracy) for all. Having worked with these themes over the past few years, I - a white, middle-class, well educated woman who was involved in both the Civil Rights Movement in my youth in DC and the feminist movement - have found race the most difficult topic I have ever incorporated into my teaching. A few students (white, black, Latina/o, or Native American) have left my course with hostilities towards the class, towards me, and towards their classmates. Growth is not always observable, but experience suggests that the process of learning sensitivity to forms of racism, sexism, and other internalized prejudices is lengthy.

Becoming political subjects: Freire (1998) and Apple (1979) argue that educators must assume the political nature of educational work. Freire indicated that teachers must know the political nature of education and be clear about their position.

Clarifying the question of in whose favor I practice, puts me in a certain position, which is related to class, in which I devise against whom I practice, and necessarily, for what reasons I practice - that is, the dream, the type of society on whose behalf I would like to intervene, act, and participate. (cited in Torres, 1998 , p. 162$)^{6}$

Freire conceived of students as "neither tabula rasa in cognitive or ethical terms nor fully equipped for the exercise of their democratic rights and obligations" (cited in Torres, p. 162). A democratic education leads towards democratic citizenship where people are responsible and able to participate in the democratic political process. They are educated with values and behavior to work towards a participatory democracy, and knowledge of democratic processes and technical performance. They are reflective thinkers and willing to act. Anthropologist Paul Rabinow (1986) uses the term "political subjects," in which ethics combines with dialogics in an effort "to create a relation with the Other" (p. 255), which Freire (1998) also talks about. These are key principles of "multicultural education" in models by Banks (1993) and Sleeter and Grant (1994).

Many teachers and pre-service teachers would like to dismiss the possibility that education teaches students to become political subjects (most recently, Kamhi, 2010). Particularly in art, they argue that it takes the "magic" out of art. Further, 
they hold an idea that education cannot, and should not, be political. Awakening to the political nature of teaching is sometimes best accomplished through concepts of visual culture. Many students are able to analyze the politics of corporate images and contemporary art, and grasp Foucault's concept of "power/knowledge," that those in power establish what counts as worthwhile knowledge in a given society, and knowledge systems reinforce power relations (Foucault, 1980). Making the transfer to education and to art from this point occurs more readily as we examine at what is taught and left out of the art curriculum.

Transgression and play. Duncum (2009) argues that visual culture educators are off base in their emphasis on understanding in teaching visual culture. Important to the young people as well as other fans of popular culture is its transgressive nature. Echoing Bakhtin (1968), he argues, "the popular culture of ordinary people is often subversive as officially approved culture is turned on its head in a 'carnivalesque' celebration of hedonistic irrationality" involving "exploration of alternative sexualities...the grotesque, the obscene, and the completely nonsensical" (p. 234). Most educators work from a rational space, which contradicts the irrationality of popular culture. Moreover, transgression is at odds with one of the hidden curricular threads of schooling, learning the rules and expectations of society.

Youth culture and social movements often appropriate consumer products and commodities and rework them so that they are infused with new meanings, meanings that are unique to their respective groups. Manifold (2009), for example, describes fan-based artworks of cosplay and fanart, cosplay involving dressing up as characters in media and fanart involving creating artworks based upon their favorite shows, comic books, etc. Both are creative forms of play involving problem-solving and learning challenges, play through which youth she interviewed experience "intense feelings" (p. 259). They also involve a collaborative social network of people with whom they share their work and ideas that are important to playing with and figuring out self-identity. Manifold argues that spontaneous play, not structured by external forces (teacher or parent, for example), is important to learning in art. Cosplay and fanart might be seen as practices of bricolage, the taking of commodities and making them one's own by giving them new meaning (Hebdige, 1979). Duncum's (2001) example of Coke's various meanings in other cultures, given earlier in this paper, would be an example of bricolage as a cultural practice; youth thrift-store fashion would be a more visual example.

The art of the last century, now canonical and therefore what is often the knowledge taught in schools, is rooted in a series of transgressions. Critics of the Impressionists, for example, accused them of putting paint in a gun and shooting it at a canvas, of being "criminals," "communists," and "enemies of beauty," and feared it would cause pregnant women to miscarry (Bersson, 2004, p. 503). Duchamp put a urinal in a 1917 exhibition to test the limits of art and taste; it was eventually displayed behind a curtain. Examples of today include elephant dung in paintings (Chris Ofili's The Holy Virgin Mary), a picture of a crucifix in urine and photos of corpses (Andres Serrano's Piss Christ), overt sexual connotations (Paul McCarthy), repeated plastic surgery to the artist's face (Orlan), and broken, sexualized female mannequins (Cindy 
Sherman). Transgressive art "cuts across basic norms or mores, and it often causes offense or is considered shocking" (Duncum, 2009, p. 232). It breaks its own rules, it breaks social taboos, and/or shows political resistance (Duncum, 2009, p. 233, citing Julius, 2003, and Mey, 2007).

Drawing on the way many artists develop and work, Gude (2007) argues that art "learning begins with creative, deeply personal, primary process play. Such play must be truly free, not directed toward mastering a technique, solving a specific problem, or illustrating a randomly chosen juxtaposition ... Students of all ages need opportunities to creatively 'mess around' with various media" (p. 7). Because students' learning is continually directed throughout their schooling, they need guidance to re-capture the generative process of play. Playing involves experimenting with media and techniques in concert with other strategies. For example, the Surrealists advocated accessing the unconscious through making and finding things that do not seem to belong together (an ironing board and an eyeball, for example). Exercises taught to students can involve making poetry using methods of chance or creating an "Exquisite Corpse," a character to which different students contribute a section without knowing what the extant sections look like. To further free up the mind, students look for images in inkblots, clouds, or spots on walls. Such activities are interspersed throughout a curriculum, returned to repeatedly.

These principles: identity, understanding beyond oneself, race/class/gender, becoming political subjects, and transgression and play constitute an approach to taking on the complexities of becoming a participatory citizen and a border crosser in a globalized world where democracy, the autonomy of the individual, and the importance of the local seem to be losing force.

\section{Concluding with Art}

In art and visual culture, teachers and scholars have a tangible hope to combine individual students' imaginations and perspectives with explorations of the political and cultural dimensions of living. The possibility to realize informed, reflective, and creative participatory citizen-artists is palpable. Art and visual culture teachers, community workers, and scholars have a vital role to play in mentoring informed, reflective, sensitive, and imaginative artists and participatory citizens.

The most headway in these areas has been made in working with the arts in community art education situations. For example, Judy Baca and a team of artists worked with youth for several summers to create an ethnic history of Los Angeles in the form of a mural. Beyond painting, students participated in workshops and field trips to experience their city's history from such perspectives (SPARC, n.d.). In my own city, at any time there are projects taking place that involve artists collaborating with youth in similar ways to create community-inspired public art projects. There are also community-based projects, such as Bicycle Inter-Community Action/Art and Salvage, that incorporate art into their broader community mission (BICAS, n.d.). Principles of community arts clearly adhere to principles of social justice and participatory citizenship by connecting art with community and culture, valuing the local 
and diversity, taking action, and (sometimes) incorporating transgression and play (Goldbard, 2006; Knight \& Schwarzman, 2006).

To date, there is less evidence of the principles presented in this paper at work in schools than in community education. This may be due to the conservative nature of many schools that support the status quo and retreat from the realities of the politics of schools, the difficulty for teachers of taking on big projects in the confines of the structure of schools, the teachers' hesitation to work outside what they perceive as the confines of schooling, or other factors. Yet there is some headway being made, particularly in university programs that support community and certification tracks (thus creating exposure to community principles and possibilities of school-community collaborations for future art teachers), and in programs that emphasize visual culture education, which is rooted in critical pedagogy (e.g., Tavin, 2003; Freedman, 2003; Garoian, 1999). Despite the corporate environment in which most people live and work, because of these trends this is an exciting time to be an art and visual culture educator, in which educators work together to teach art and visual culture as part of citizenship in a participatory democracy.

\section{Notes}

1. Under the term “Jihad," Barber (1995) indicates any dogmatic and militant group. His argument is that whereas fundamentalist religion and corporate culture may be ideologically opposed, and are thus driven by different forces, "the one driven by parochial hatreds, the other by universalizing markets" (p. 6), neither respects the principles and ideals that underlie democracies.

2. Torres (1998) defines "postcolonialism" as "a theoretical perspective connected with liberation movements fighting against colonialism and racism [that] emerged as an attempt to criticize the rational foundations of colonialism and to decolonize 'the mind,"' (p. 121). It is "above all a criticism of the Enlightenment and its legacy of modernity. As does feminism, postcolonialism criticizes the notion of an unqualified reason, universality, the progressive unfolding of history, national sovereignty, and the integrity of a self-identity subject that holds specific, self-reflective interests. Like feminism, postcolonial discourse has had a significant impact on cultural studies, the discourse of minority representation, and most of the discussions in humanities on dramatic, literary, cinematic, artistic, and musical texts" (p. 121).

3. As a term, "multiculturalism" is "baggy," serving a variety of interests, goals, and values (Torres, 1998, p. 180). It is also thought to be "outdated" in some research circles, even though the problems posed by multicultural reform educators are not obsolete: quite the contrary.

Research by Banks (1993) indicates four approaches to multiculturalism: "corporate and conservative multiculturalism": teaching about contributions of different cultural groups and individuals; "liberal multiculturalism": adding multicultural lessons as supplement to the existing curriculum; "transformative multiculturalism": changing the basic curriculum and instruction to reflect the perspectives and experiences of diverse groups; and "policy making approach": teaching students that inter-group relations are always an integral part of social and historical conflicts and that students should employ political action to achieve greater equality, freedom, and social justice.

Similarly, Sleeter and Grant's (1987) research resulted in five approaches to multicultural 
education: "teaching the culturally different" to fit into "mainstream" society; "human relations," emphasizing different groups living together harmoniously; "single-group studies," in which students learn to develop awareness, respect, and acceptance of specific groups in society; "multicultural: in which the focus is on reducing prejudice and creating equal educational opportunities and social justice; and "social reconstructionist," in which analytical and critical thinking are paired with political actions focused on the redistribution of society's resources, especially power and wealth, among diverse groups.

4. In a talk at the UNESCO $20102^{\text {nd }}$ World Conference on Arts Education, KoreanAmerican composer KIM, Hi Kyung similarly noted how her identity shifted, moving from the United States to France from a "Korean" composer to an "American" composer (Kim, 2010).

5. Helms' $(1990,1994,1995)$ model of white racial identity includes three stages (or as she now calls them "statuses" [Helms, 1995]) of movement away from racism: contact, in which racism is not really examined; disintegration, in which the person realizes that his/ her world is constructed systematically along racial lines; reintegration, in which the person believes people of colour should learn to adapt to whatever are the perceived norms; pseudoindependence, in which the person actively works to abandon racism, particularly from an intellectual and "assisting" position; immersion-emersion, in which racism is confronted on both emotional and intellectual terms and the person turns to his or her own race to solve racial problems; and autonomy, in which the person has fully internalized a flexible view of the world and people in it, values and seeks out cross-racial and cross-cultural experiences, and views him or herself in a non-comparative way. Her model of racial identity for people of colour is based on surmounting internalized racism in its various manifestations. Statuses are conformity, in which the person devalues their own racial group by conforming to White standards and is oblivious to socio-racial issues; dissonance/ encounter, in which the person experiences ambivalence and confusion concerning their commitment to their own racial definition and group; immersion/emersion, in which the person idealizes their own racial group and opposes what $s /$ he perceives as white; internalization, in which the person maintains a positive commitment to their own racial group, as well as responds objectively to members of the dominant group; and integrative awareness, in which a person values their own collective identities and also collaborates and empathizes with members of other oppressed groups.

6. Once, when we were studying gender issues and students were to create a self-portrait based on their gender identity, a male student asked if he could do a portrait of one of the female students at the table because women really had gender identity issues but he just was. This has stood out, for me, as an example of the difficulty of confronting one's own identity in comparison to learning about people different from oneself.

\section{References}

Apple, M.W. (1979). Ideology and curriculum. London \& Boston: Routledge \& Kegan Paul. Aoun, I. (2010). The reinforcement of socio-cultural dimensions of arts education in the promotion of cultural diversity, social cohesion and society issues. Proceedings. The $2^{\text {nd }}$ World Conference on Arts Education (pp. 64-65). Seoul: Ministry of culture, Sports, and Tourism, UNESCO.

Bae, M.S. (2009). Global new femininity in mediascape: Korean teenage girls' popular cultural practices. In E. Delacruz, A. Arnold, A. Kuo, \& M. Parsons (Eds.), Globalization and art education (pp. 179-185). Reston, VA: National Art Education Association. 
Bagdikian, B.H. (2000). The media monopoly (6 $6^{\text {th }}$ ed.). Boston, MA: Beacon

Bakhtin, M. (1968). Rabelais and his world. (H. Iswolsky, Trans.). Cambridge: Institute of Technology.

Banks, J.A. (1993). Approaches to multicultural curriculum reform. In J.A. Banks \& C.A. McGee Banks (Eds.), Multicultural education: Issues and perspectives (pp. 247-270). Boston, MA: Allyn \& Bacon.

Barber, B. R. (1995). Jihad vs. McWorld. New York, NY: Times Books/ Random House.

Baudrillard, J. (2002). Jean Baudrillard: Selected writing (2 $2^{\text {nd }}$ ed.). M. Poster \& J. Mourrain (Eds.). Palo Alto, CA: Stanford.

Bersson, R. (2004). Responding to art: Form, content, and context. Boston: McGraw Hill.

BICAS. (n.d.). Bicycle Inter-community Action/Art and Salvage. [On-line]. Available: http://www.bicas.org

Bourdieu, P. (1984). Distinction: A social critique of the judgment of taste. Cambridge, MA: Harvard University.

Burbules, N.C., \& Torres, C.A. (2000). Globalization and education: An introduction. In N. Burbules \& C. A. Torres (Eds.), Globalization and education: Critical perspectives, pp. 1-26. New York, NY: Routledge.

Chakrabarty, D. (2000). Provincializing Europe: Postcolonial thought and historical difference. Oxford, UK \& Princeton, NJ: Princeton University.

Clifford, J. (1988). The predicament of culture. Cambridge, MA: Harvard.

Duncum, P. (2001). Theoretical foundations for an art education of global culture and principles for classroom practice [Electronic version]. International Journal of Education and the Arts, 2(3), 1-15. [On-line]. Available: http://www.ijea.org/v2n3/index.html

Duncum, P. (2009). Toward a playful pedagogy: Popular culture and the pleasures of transgression. Studies in Art Education, 50(3), 232-244.

Foucault, M. (1980). Power/knowledge: Selected interviews and other writings 1972-1977 (C. Gordon, Ed.; C. Gordon, L Marshall, J. Mepham, \& K. Soper, Trans.). New York: Pantheon.

Freedman, K. (2003). Teaching visual culture: Curriculum, aesthetics, and the social life of art. New York: Teachers College \& Reston, VA: National Art Education Association.

Freire, P. (1998). Pedagogy of the oppressed. Trans. M.B. Ramos. New York, NY: Continuum.

Garber, E. (1995). Teaching art in the context of culture: A study in the borderlands. Studies in Art Education, 36(4): 218-232.

Garber, E., Sandell, R., Stankiewicz, M.A., \& Risner, D. (2007). Gender equity in visual arts and dance education. In S. Klein (Ed.), Handbook for achieving gender equity through education (pp. 359-380). Mahwah, NJ: Lawrence Ehrlbaum.

Garoian, C. (1999). Performing pedagogy: Toward an art of politics. Albany, NY: State University of New York.

Giroux, H. (1992). Border crossings: Cultural workers and the politics of education. New York, NY \& London, UK: Routledge.

Gitlin, T. (1995). The twilight of common dreams: Why America is wracked by culture wars. New York, NY: Henry Holt.

Goldbard, A. (2006). New creative community: The art of cultural development. Oakland, CA: New Village.

Gomez-Peña, G. (1986). Border culture: A process of negotiation toward utopia. La Linea Quebradal The Broken Line, (1), 1-6.

Grauer, K. (2002). Teenagers and their bedrooms. Visual Arts Research, 9(1), 86-94.

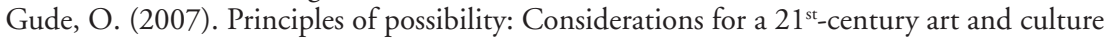
curriculum. Art Education, 60(1), 6-17.

Hebdige, D. (1979). Subculture: The meaning of style. New York: Routledge.

Held, D. (1995). Democracy and global order: From the modern state to cosmopolitan governance. Cambridge, UK: Polity. 
Helms, J. (Ed.) (1990). Black and white racial identity: Theory, research, and practice. New York, NY: Greenwood Press.

Helms, J. E. (1994). The conceptualization of racial identity and other "racial constructs." In E.J. Trickett, R.J. Watts, \& D. Briman (Eds.), Human diversity: Perspectives on people in context (pp. 285-311). San Francisco: Jossey-Bass.

Helms, J.E. (1995). An update of Helms's white and people of color racial identity models. In J.G. Ponterotto, J.M. Casas, L.A. Suzuki, \& C.M. Alexander (Eds.), Handbook of multicultural counseling (pp. 181-198). Thousand Oaks, CA: SAGE.

Howe, D. (1996). Introduction: Commodities and cultural borders. In D. Howe (Ed.), Cross-cultural consumption: Global markets, local realities (pp. 1-16). London: Routledge.

jagodzinski, j. (2008). Postmetaphysical vision: Art education's challenge in an age of globalized aesthetics (a mondofesto). Studies in Art Education, 49(2), 147-160.

jagodzinski, j. (2010). Advocating the socio-cultural values and impact of arts education. Proceedings. The $2^{\text {nd }}$ World Conference on Arts Education (67-68). Seoul: Ministry of culture, Sports, and Tourism, UNESCO.

Julius, A. (2003). Transgressions: The offences of art. Chicago, IL: University of Chicago.

Kamhi, M.M. (2010, April). The hijacking of art education. Aristos: An online review of the arts. [On-line]. Available: http://www.aristos.org/aris-10/hijacking.htm

Kim, H. (2009). Globalization and cultural diversity: Shifts in the cultural terrain in Korea. In E. Delacruz, A. Arnold, A. Kuo, \& M. Parsons (Eds.), Globalization and art education (pp. 20-26). Reston, VA: National Art Education Association.

Kim, H.K. (2010). Responding to the challenges of arts education: Tensions between traditional and contemporary practices and transcending geo-cultural differences. Proceedings. The $2^{\text {nd }}$ World Conference on Arts Education (pp. 31-39). Seoul: Ministry of culture, Sports, and Tourism, UNESCO.

Knight, K., \& Schwarzman, M. (2006). Beginner's guide to community-based arts. Oakland, CA: New Village.

Kozol, J. (1991). Savage inequalities: Children in America's schools. New York, NY: Crown.

Lippard, L. (1990). Women, art, and cross-cultural issues [From article Teachers teaching teachers: Some notes from campuses]. Heresies, 7(1), p. 53. [On-line] Available: http:// helios.hampshire.edu/nomorenicegirls/heretics/\#archive5

Lyndersay, D. (2010). The socio-cultural dimensions of the transformational elements of arts education in the promotion of cultural diversity, social cohesion and societal issues for societies-in-crisis. Proceedings. The $2^{\text {nd }}$ World Conference on Arts Education (pp. 64-65). Seoul: Ministry of culture, Sports, and Tourism, UNESCO.

Macpherson, C.B. (1962). The political theory of possessive individualism: Hobbes to Locke. Oxford, UK: Oxford University.

Macpherson, C.B. (1973). Democratic theory: Essays in retrieval. Oxford, UK: Oxford University.

Manifold, M. (2009). What art educators can learn from the fan-based artmaking of adolescents and young adults. Studies in Art Education, 50(3), 257-271.

McIntosh, P. (1988). White privilege and male privilege: A personal account of coming to see correspondences through work in women's studies. Wellesley, MA: Wellesley College Center for Research on Women, Working Paper no. 189. Reprinted as: McIntosh, P. (1989). White privilege: Unpacking the invisible knapsack. Peace and Freedom (July/ August), 10-12.

McLaren, P. (1997). Unthinking whiteness, rethinking democracy: Critical citizenship in gringolandia. In P. McLaren (Ed.), Radical multiculturalism: Pedagogies of dissent for the new millennium. Boulder, CO \& Oxford, UK: Westview.

Mey, K. (2007). Art and obscenity. London: I.B. Taurus.

Morley, D., \& Robins, K. (1995). Spaces of identity: Global media, electronic landscapes, and cultural boundaries. London, UK: Routledge. 
Pillai, J. (2010). Cultural collectives in Southeast Asia: Initiating change in community consciousness through engaged arts. Proceedings. The $2^{\text {nd }}$ World Conference on Arts Education (pp. 123-124). Seoul: Ministry of culture, Sports, and Tourism, UNESCO.

Rabinow, P. (1986). Representations are social facts: Modernity and post-modernity in anthropology. In J. Clifford \& G. Marcus (Eds.), Writing culture: The poetics and politics of ethnography, pp. 234-261. Berkeley, CA: University of California.

Roman, L. (1993). "White is a color? White defensiveness, postmodernism, and anti-racist pedagogy. In C. McCarthy \& W. Crichlow (Eds.), Race, identity, and representation in education. New York, NY: Routledge.

Sadker, M., \& Sadker, D. (1995). Failing at fairness: How our schools cheat girls. New York: Scribner.

Said, E. (1993). Culture and imperialism. New York: Knopf.

Sleeter, C.E. \& Grant, C.A. (1994). Making choices for multicultural education: Five approaches to race, class, and gender. New York, NY: Merrill.

SPARC. (n.d.). The Great Wall resource portal. (The Social and Public Art Resource Center). [On-line]. Available: http://www.sparcmurals.org:16080/sparcone/index. php?option=com_content\&task=view\&id=20\&Itemid $=52$

Stanley, N. (2005). Out of this world: Theme parks' contribution to a redefined aesthetics and educational practice. In R. Hickman (Ed.), Critical studies in art and design education (pp. 163-185). Bristol, UK: Intellect.

Tavin, K. (2003). Wrestling with angels, searching for ghosts. Studies in Art Education, 44(3), 197-213.

Tavin, K., \& Hausman, J. (2004). Art education and visual culture in the age of globalization. Art Education, 57(5), 47-52.

Toku, M. (2001). What is manga? The influence of pop culture in adolescent art. Art Education, 54(2), 11-17.

Torres, C.A. (1998). Democracy, education, and multiculturalism: Dilemmas of citizenship in a global world. Lanham, MD: Rowman \& Littlefield.

Ward, J. (2010). Roots \& branches - from the local to the global; A case study of long-term international engagement grown from seeds in rural NE England. Proceedings. The $2^{\text {nd }}$ World Conference on Arts Education (78-80). Seoul: Ministry of culture, Sports, and Tourism, UNESCO.

Wasson, R.F., Stuhr, P.L., \& Petrovich-Mwaniki, L. (1990). Teaching art in the multicultural classroom: Six position statements. Studies in Art Education, 31(4), 234-246.

West, Cornell. (1994). Race matters. New York, NY: Vintage.

Ybarra-Fausto, T. (1986). "Introduction" to I. Lockpez (Project Director), Chicano expressions: A new view in American art [exh. cat.]. New York, NY: Intar Latin American Gallery. 